\title{
Papaya fruits extracts enhance the antioxidant capacity and modulate the genotoxicity and oxidative stress in the kidney of rats fed ochratoxin A-contaminated diet
}

\author{
Aziza A. El-Nekeety ${ }^{1}$, Khaled G. Abdel-Wahhab ${ }^{2,}$, Sekena H. Abdel-Aziem³ ${ }^{3}$ Fathia A. Mannaa ${ }^{2}$, Nabila S. Hassan ${ }^{4}$, \\ Mosaad A. Abdel-Wahhab ${ }^{1 *}$ \\ ${ }^{1}$ Food Toxicology \& Contaminants Dept., National Research Center, Dokki, Cairo, Egypt. ${ }^{2}$ Mdical Pathology Dept., National Research Center, Dokki, \\ Cairo, Egypt. ${ }^{3}$ Cell Biology Dept., National Research Center, Dokki, Cairo, Egypt. ${ }^{4}$ Pathology Dept., National Research Center, Dokki, Cairo, Egypt.
}

\begin{tabular}{|c|c|}
\hline ARTICLE INFO & ABSTRACT \\
\hline Article history: & \multirow{13}{*}{$\begin{array}{l}\text { Ochratoxin A (OTA) is a mycotoxin widespread contaminates food and has potent nephrotoxicity. The present } \\
\text { study aimed to determine total phenolics and DPPH radical scavenging activity for water and ethanolic extracts } \\
\text { (WE and EE) of papaya fruits and evaluation of the protective role of these extracts against OTA-induced } \\
\text { oxidative damage and nephrotoxicity in rats. Sixty male Sprague-Dawley rats were divided into six groups and } \\
\text { treated for } 21 \text { days as follow: the control group, OTA-treated group ( } 3 \mathrm{mg} / \mathrm{kg} \text { diet), WE or EE extracts treated } \\
\text { groups }(250 \mathrm{mg} / \mathrm{kg} \text { b.w) and OTA plus WE or EE-treated groups. Blood and kidney samples were collected for } \\
\text { different biochemical, cytogenetical and histological analyses. The results showed that WE and EE contained } \\
408.54 \text { and } 296.85 \mathrm{~g} / \mathrm{kg} \text { total phenolic, respectively and DPPH radical scavenging activity was higher in WE } \\
\text { than EE. Animals fed OTA-contaminated diet showed signs of toxicity as indicated by the significant decrease } \\
\text { in body weight gain and food intake, the disturbances in kidney biochemical indices, increase DNA } \\
\text { fragmentation and oxidative stress markers, the decrease in antioxidant enzymes activities and gene expression } \\
\text { as well as severe histological and histochemical changes in the kidney tissues. Both extracts succeeded to } \\
\text { counteract these alterations and WE was more effective than EE. These results concluded that papaya fruits } \\
\text { extracts succeeded to a great extant to counteract the oxidative stress of OTA and to protect the kidney against } \\
\text { its toxic effects and may be promising candidate as food supplement for the protection against OTA in high } \\
\text { endemic area. }\end{array}$} \\
\hline $8 / 12 / 2016$ & \\
\hline Accepted on: 20/02/2017 & \\
\hline Available online: $30 / 07 / 2017$ & \\
\hline Key words: & \\
\hline Ochratoxin A; mycotoxins; & \\
\hline kidney; oxidative stress; & \\
\hline & \\
\hline & \\
\hline & \\
\hline & \\
\hline & \\
\hline & \\
\hline
\end{tabular}

\section{INTRODUCTION}

Ochratoxin A (OTA) is a mycotoxin produced by Aspergillus ochraceus in the warm and the tropical countries and by Penicillium verrucosum in temperate climates (Santos et al., 2010; Iqbal et al., 2013). OTA has classified by IARC as group 2B carcinogen, probable human carcinogen (IARC, 2002) and can contaminate several agriculture crops, especially grains. This mycotoxin is stable to heat treatment and can enter the food chain either through the raw or the processed products in addition to

\section{* Corresponding Author}

Mosaad A Abdel-Wahhab, Food Toxicology \& Contaminants Dept., National Research Center, Dokki, Cairo, Egypt.

Email:mosaad_abdelwahhab@yahoo.com through the animal-origin products derived from the livestock fed with contaminated feed (EFSA, 2006; FAO, 2012). OTA exposure is a worldwide problem and it is detected in human sera in several countries (Duarte et al., 2011; Märtlbauer et al., 2009; Soto et al., 2016). Previous studies have indicated that exposure to OTA results in a number of diseases in both animals and humans and mainly affect the kidney. Moreover, it is also responsible for neurotoxicity, immunotoxicity, myelotoxicity, teratogenicity and reproductive toxicity in different animal species (Heussner and Bingle, 2015; Cariddi et al., 2016; Abdel-Wahhab et al., 2016; Costa et al., 2016). OTA is also responsible to Balkan endemic nephropathy (BEN) and associated with urothelial tumors in human (Pfohl-Leszkowicz et al., 2007). 
The World Health Organization (WHO, 2008) suggested five hypotheses as main contributors (collectively or individually) to the mode of action of OTA including (1) the genotoxicity resulted from direct interaction of OTA or its reactive metabolite with DNA; (2) generation of tumors secondary to chronic renal toxicity and compensatory cell proliferation; (3) generation of tumors secondary to inhibition of phenylalanine-tRNA ${ }^{\text {Phe }}$ synthetase and protein synthesis; (4) mitochondrial dysfunction leading to oxidative stress and indirect induction of DNA damage; and (5) disruption of cell-cell signaling pathways and the process of cell division. The EFSA (European Food Safety Authority) and the JECFA (Joint FAO/WHO Expert Committee on Food Additives) have set a Tolerable Weekly Intake (TWI) and Provisional Tolerable Weekly Intake (PTWI) for OTA at 120 (EFSA, 2006) and $100 \mathrm{ng} / \mathrm{kg}$ body weight (JECFA, 2008), respectively. Papaya (Carica papaya L.) is a fruit cultivated widely all over the world, particularly in tropical countries. It is extremely appreciated because of its sensory characteristics, its highly nutritional value and digestive characteristic (Paes et al., 2015). Papaya fruits contain two main biologically active compounds namely papain and chymopapain which are widely used for the treatment of digestive disturbance (Huet et al., 2006). These fruits also contain caricain, and glycerin endopeptidase which have the ability to improve the acidic $\mathrm{pH}$ conditions and the degradation of pepsin (Kokila et al. 2016).

Moreover, papaya contains other active compounds including a variety of phytochemicals such as natural phenols (Khan et al., 2012) and polyphenols which inhibit the oxidation of biomolecules through their free radicals scavenging properties (Urquiaga and Leighton, 2000) or through the enhancement of endogenous antioxidant enzymes activities (La Marca et al., 2012) consequently, prevent the onset of different chronic diseases in humans. According to Dominguez de Maria et al. (2006), papaya fruits are rich in lipase and ahydrolase which are tightly bonded to the water-insoluble fraction of crude papain thus consider as a "naturally immobilized" biocatalyst. The aims of the present study were to determine total phenolics and DPPH radical scavenging activity for water and ethanolic extracts of papaya fruits and evaluation their protective effects against oxidative stress and renal toxicity in rats fed OTA-contaminated diet.

\section{MATERIALS AND METHODS}

\section{Chemicals and kits}

OTA standards and 1,1-Diphenyl-2-picrylhydrazyl (DPPH), sodium tripolyphosphate (TPP) and RevertAid ${ }^{\mathrm{TM}} \mathrm{H}$ Minus First Strand cDNA Synthesis Kit were purchased from Sigma Chemical Co. (St. Luis, Mo, USA). Kits of creatinine and urea were obtained from Randox Laboratories LTD Co. (UK.). Total antioxidant capacity (TAC) and lipid peroxidation (MDA) kits were obtained from Biodiagnostic Co. (Giza, Egypt). TRIZOL reagent was purchased from Invitrogen ${ }^{\mathrm{TM}}$ (Carlsbad, CA, USA). All other chemicals were of the highest purity commercially available.

\section{Plant materials}

Papaya (Carica papaya L.) fruits were collected from a private plantation located in Qalubia region (Egypt) during June 2015. The fruits were identified in the Fruits Department, National Research Centre and the voucher was kept in the herbarium of NRC. The amount of plant used was $500 \mathrm{~g}$.

\section{Preparation of papaya extracts}

Fresh fruits of papaya were cut into small pieces, dried and finally ground with a blender into powder form. A crude ethanolic extract was prepared by soaking and stirring the powder in absolute ethanol (200 g/500 $\mathrm{ml}$ ethanol) for 3 days. The extract was filtered and the residue was re-extracted twice using ethanol. The pooled extract was vacuum-dried at $40 \circ \mathrm{C}$. Aqueous extract was prepared by maceration process. The filtrate was subjected to lypholyzation process using Freeze Dryer system (Dura-Dry Freeze Dryer, Model PAC-TC-V4; FTS system, Inc., Stone Ridge, NY, USA) under pressure, 0.1 to $0.5 \mathrm{mbar}$ and temperature -35 to $41^{\circ} \mathrm{C}$ conditions. Both the dry ethanolic and aqueous extracts were stored at $-20{ }^{\mathrm{O}} \mathrm{C}$ until analysis. These procedures resulted in an approximate yield of $13 \%(\mathrm{w} / \mathrm{w})$ of ethanolic extract (EE) and 27 $\%(\mathrm{w} / \mathrm{w})$ of aqueous extract (AE) based on the dry weight.

\section{Determination of total phenolic compounds}

Five $\mathrm{mg}$ of the extract were dissolved in a $10 \mathrm{ml}$ mixture of acetone and water $(6: 4 \mathrm{v} / \mathrm{v})$. Samples $(0.2 \mathrm{ml})$ were mixed with $1.0 \mathrm{ml}$ of 10 - fold diluted Folin-Ciocalteu reagent and $0.8 \mathrm{ml}$ of sodium carbonate solution (7.5\%). After $30 \mathrm{~min}$ at room temperature, the absorbance was measured at $765 \mathrm{~nm}$ using V-530 UV/visible spectrophotometer. Estimation of phenolic compounds as catechin equivalents was carried out using standard curve of catechin (Jayaprakasha et al., 2003).

\section{Determination of radical scavenging activity by DPPH assay}

Certain of crude extracts were dissolved in methanol to obtain a concentration of $200 \mathrm{ppm}$. A volume of $0.2 \mathrm{ml}$ of this solution was completed to $4 \mathrm{ml}$ by methanol and $1 \mathrm{ml} \mathrm{DPPH}$ solution $\left(6.09 \times 10^{-5} \mathrm{~mol} / \mathrm{L}\right)$ in the same solvent was then added. The absorbance of the mixture was measured at $516 \mathrm{~nm}$ after 10 min standing. The reference sample (blank) was $1 \mathrm{ml}$ of DPPH solution and $4 \mathrm{ml}$ methanol. Triplicate measurements were made and the antioxidant activity was calculated by the percentage of DPPH that was scavenged according to Nogala-Kalucka et al. (2005).

\section{Ochratoxin A (OTA) production}

OTA was produced through the fermentation of corn by Aspergillus ochraceus (NRRL 3174) as described by Varga et al. (1996). The fermented corn was autoclaved, ground to a powder and the OTA content was measured by the high-performance liquid chromatography (HPLC) according to Xiao et al. (1995). he corn powder was incorporated into the basal diet to provide the desired level of $3 \mathrm{mg}$ OTA $/ \mathrm{kg}$ diet. The diet containing OTA was analyzed and the presence of OTA was confirmed by HPLC. 


\section{Experimental animals}

Three months old male Sprague-Dawley rats (120-130 g were purchased from the Animal House Colony, Giza, Egypt) and were maintained on standard lab diet (protein: 160.4; fat: 36.3; fiber: $41 \mathrm{~g} / \mathrm{kg}$ and metabolizable energy $12.08 \mathrm{MJ}$ ) in artificial illuminated and temperature controlled room free from any other source of chemical contamination at the Animal House Laboratory, National Research Center, Dokki, Cairo, Egypt. After an acclimatization period of 1 week, the animals were divided into six groups (10 rats/group) and housed in filter-top polycarbonate cages. All animals were received humane care in compliance with the guidelines of the Animal Care and Use Committee of the National Research Center, Dokki, Cairo, Egypt and the National Academy of Sciences (NIH publication 86-23 revised 1985).

\section{Experimental design}

Animals within treatment groups were maintained on their respective diets for 3 weeks as follows: group 1, untreated control; group 2, fed OTA-contaminated diet (3 mg/kg diet); group 3 , treated orally with EE $(250 \mathrm{mg} / \mathrm{kg} \mathrm{b}$. w.); group 4, treated orally with AE (250 mg/kg b.w.); groups 5 and 6, fed OTA-contaminated diet and treated orally with EE or AE. The animals were fed restrictively ( $~ 0.8$ of ad libitum intake, $20 \mathrm{~g} / \mathrm{d}$ ) to avoid differences in OTA intake and were observed daily for any signs of toxicity during the experimental period. Food intake was recorded each other day and body weight gain was recorded twice a week throughout the experimental period. At the end of the experimental period, fasting blood samples were collected from the retro-orbital venous plexus under ether anesthesia. The blood samples were left to clot and then centrifuged at $3000 \mathrm{rpm}$ for 15 minutes to separate sera which were used for the determination of different biochemical parameters according to the kits instructions using spectrophotometer. After the collection of blood samples, all animals were rapidly killed and a whole kidney of each animal was dissected and divided longitudinal into two halves. The first half was used for the molecular analyses and the second half was washed with saline and immediately homogenized in ice-cold buffer containing $50 \mathrm{mM}$ tris- $\mathrm{HCl}$ and $300 \mathrm{mM}$ sucrose (pH 7.4) to give $10 \% \mathrm{w} / \mathrm{v}$ homogenate (Tsakiris et al., 2004). The homogenate was centrifuged at $3000 \mathrm{rpm}$ at $0^{\circ} \mathrm{C}$ for 10 minutes and the supernatant was stored at $-20{ }^{\circ} \mathrm{C}$ to the second day until analysis. This supernatant (10\%) was used for the determination of malondialdehyde (MDA) by the spectrophotometric method described by Ruiz-Larnea et al. (1994), total antioxidant capacity (TAC) levels as described by Koracevic et al. (2001) and $\mathrm{Na}+$ / K+-ATPase activity according to the modified chemical method that described by Tsakiris et al. (2000). The homogenate was further diluted with phosphate buffer solution to give $2 \%$ and $0.5 \%$ dilutions for the determination of renal GPx (2\%) and SOD $(0.5 \%)$ activities. The second whole kidney from each animal was fixed in $10 \%$ neutral formalin and paraffin embedded. Sections $(5 \mu \mathrm{m}$ thickness) were stained with hematoxylin and eosin (H \& E) for the histological examination. Other sections from kidney were stained with Bromophenol blue for the determination of total protein content in the whole kidney tissue (Drury and Wallington 1980).

\section{Molecular analyses \\ DNA fragmentation}

Samples of the second half of each kidney were lysed in $0.5 \mathrm{ml}$ of lysis buffer containing $10 \mathrm{mM}$ tris- $\mathrm{HCl}(\mathrm{pH} 8), 1 \mathrm{mM}$ EDTA and $0.2 \%$ triton $\mathrm{X}-100$. The content was centrifuged at $10,000 \mathrm{rpm}$ for $15 \mathrm{~min}$ at $4{ }^{\circ} \mathrm{C}$ to separate intact chromatin in the pellet from fragmented/damaged DNA in the supernatant. The pellets were resuspended in $0.5 \mathrm{~N}$ perchloric acid $(\mathrm{P})$ and $5.5 \mathrm{~N}$ perchloric acid was added to the supernatants $(\mathrm{S})$ to obtain a final concentration of $6.0 \mathrm{~N}$. Samples were incubated at $90{ }^{\circ} \mathrm{C}$ for 20 min and centrifuged at $10,000 \mathrm{rpm}$ for $10 \mathrm{~min}$ to remove proteins. A volume of $160 \mathrm{ml}$ of diphenylamine (DPA) solution [150 mg DPA in $10 \mathrm{ml}$ glacial acetic acid, $150 \mathrm{ml}$ of sulfuric acid and $50 \mathrm{ml}$ acetaldehyde $(16 \mathrm{mg} / \mathrm{ml})$ ] was added to each sample and incubated at room temperature for $24 \mathrm{~h}$ (Gibb et al., 1997). The absorbance was measured at $600 \mathrm{~nm}$ using a UV doublebeam spectrophotometer (Shimazu Co. Ltd., Tokyo, Japan). The proportion of fragmented DNA was calculated from absorbance reading at $600 \mathrm{~nm}$ using the formula:

$\%$ Fragmented DNA $=[\mathrm{OD}(\mathrm{S}) / \mathrm{OD}(\mathrm{S})+\mathrm{OD}(\mathrm{P})] \mathrm{X} 100$

Where: $\mathrm{OD}(\mathrm{S})$ optical density of supernatant

$\mathrm{OD}(\mathrm{P})$ optical density of pellet

\section{RNA extraction}

Samples of frozen kidney tissues (50-100 $\mu \mathrm{g})$ were thawed and homogenized in TRIZOL reagent. The solution of extracted RNA was recovered in $100 \mu$ molecular biology grade water. The total RNA samples were pretreated by DNA-free ${ }^{\mathrm{TM}}$ DNase to remove any possible genomic DNA contamination according to manufacturer's protocol. The quality of RNA was determined using spectrophotometer at $260 \mathrm{~nm}$ by UV visualization of an ethidium bromide-stained agarose-formalin gel.

\section{Reverse transcription}

Single strand cDNA was synthesized for PCR (Spectrum Laboratory Products, Inc. (New Brunswick, NJ, USA) and seminested PCR purposes using total RNA isolated from kidney tissues and oligo $(\mathrm{dT})_{18}$ as primer for reverse transcriptase. The reaction mixture of $20 \mu \mathrm{l}$ used in the 1st step of cDNA synthesis included 4 $\mu \mathrm{l}$ of total RNA $(2 \mu \mathrm{g}), 0.5 \mu \mathrm{l}$ oligo(dT) $)_{18}(10 \mu \mathrm{M})$, and $5 \mu \mathrm{l}$ of DEPC-treated water. The reaction mixture was incubated at $70{ }^{\circ} \mathrm{C}$ for $5 \mathrm{~min}$. A $4 \mu \mathrm{l}$ of $5 \mathrm{X}$ M-MuLV-Reverse Transcriptase buffers, 2 $\mu \mathrm{l}$ of $10 \mathrm{mM}$ dNTP mix, $0.5 \mu \mathrm{l}$ of $\mathrm{dH}_{2} \mathrm{O}$ and $0.5 \mu \mathrm{l}$ (20 units) of ribonuclease inhibitor was added to the above reaction mixture. The above mixtures were further incubated at $37^{\circ} \mathrm{C}$ for $5 \mathrm{~min}$ and $2 \mu \mathrm{l}$ M-MuLV-Reverse Transcriptase (40 units) was then added and cDNA was synthesized for $60 \mathrm{~min}$ at $42{ }^{\circ} \mathrm{C}$. The reaction was stopped by heating the reaction mixture at $70{ }^{\circ} \mathrm{C}$ for $10 \mathrm{~min}$. The synthesized cDNA was stored at $-20^{\circ} \mathrm{C}$. 
Table 1: Details giving primer sequences and expected product sizes for the genes amplified.

\begin{tabular}{|c|c|c|c|c|}
\hline cDNA & $\begin{array}{c}\text { Genbank Accession } \\
\text { No. }\end{array}$ & Forward primer & Reverse primer & $\begin{array}{c}\text { RT-PCR product } \\
\text { size }\end{array}$ \\
\hline$\beta$-actin & V01217 & 5'-CTGCTTGCTGATCCACA & 5'-CTGACCGAGCGTGGCTAC & $505 b p$ \\
\hline $\mathrm{Cu}-\mathrm{Zn}$ SOD & X05634 & 5'-GCAGAAGGCAAGCGGTGAAC & 5'-TAGCAGGACAGCAGATGAGT & $387 \mathrm{bp}$ \\
\hline GPx I & M21210 & 5'-CTCTCCGCGGTGGCACAGT & 5'-CCACCACCGGGTCGGACATAC & $290 \mathrm{bp}$ \\
\hline
\end{tabular}

$\mathrm{Cu}-\mathrm{Zn}$ SOD - copper zinc superoxide dismutase; GPx I- glutathione peroxidase

\section{Polymerase chain reaction (PCR)}

The first-strand cDNA from different kidney samples was used as the template for amplification by the PCR with the pairs of specific primers presented in Table (1) (from 5'to3') according to Limaye et al. (2003). $\beta$-actin, a house-keeping gene was used for normalizing mRNA levels of the target genes. The PCR cycling parameters were one cycle of $94{ }^{\circ} \mathrm{C}$ for $5 \mathrm{~min}, 35$ cycles of $94{ }^{\circ} \mathrm{C}$ for $30 \mathrm{~s}, 60{ }^{\circ} \mathrm{C}$ for $30 \mathrm{~s}, 70{ }^{\circ} \mathrm{C}$ for $40 \mathrm{~s}$, and $72{ }^{\circ} \mathrm{C}$ for $5 \mathrm{~min}$ for $\mathrm{Cu}-\mathrm{Zn}$ SOD using hydrogen peroxidae and for GPx I gene using horseradish peroxidase substrate according to the instructions supplied by the producer company. The PCR product was run on a $1.5 \%$ agarose gel in Tris-borate-EDTA buffer and visualized over a UV Trans-illuminator. The ethidium bromidestained gel bands were scanned and the signal intensities were quantified by the computerized Gel-Pro (version 3.1 for window 3 ). The ratio between the levels of the target gene amplification product and the $\beta$-actin (internal control) was calculated to normalize for initial variation in the sample concentration as a control for reaction efficiency (Raben et al., 1996). All PCRs were independently replicated three times.

\section{Statistical analysis}

All data were statistically analyzed using the General Linear Models Procedure of the Statistical Analysis System (SAS, 1982). The significance of the differences among treatment groups was determined by Waller-Duncan k-ratio (Waller and Duncan, 1969). All statements of significance were based on probability of $\mathrm{P} \leq 0.05$.

\section{RESULTS}

The present results showed that the water extract of papaya fruits contain $408.54 \mathrm{~g} / \mathrm{kg}$ total phenolic however the ethanol extract contain $296.85 \mathrm{~g} / \mathrm{kg}$ (Table 2). Moreover, the DPPH radical scavenging activity (SA) for these extracts recorded $32.73 \%$ and $18.87 \%$ for the water and ethanolic extracts, respectively (Table 2 ).

Table 2: Total phenolic content and DPPH radical scavenging activity of the water and ethanolic extract of papaya fruits

\begin{tabular}{|c|c|c|}
\hline Parameter & $\begin{array}{c}\text { Water extract } \\
\text { (WE) }\end{array}$ & $\begin{array}{c}\text { Ethanol } \\
\text { extract }(\mathrm{EE})\end{array}$ \\
\hline Total phenolic content $(\mathrm{g} / \mathrm{kg})$ & $408.54 \pm 12.38$ & $296.85 \pm 14.25$ \\
\hline DPPH radical scavenging activity $(\%)$ & $32.73 \pm 2.67$ & $20.75 \pm 3.26$ \\
\hline
\end{tabular}

In the in vivo assay, WE and EE of papaya fruits were evaluated for their protective role against OTA-induced kidney damage in rats. The experimental animals within different groups were appeared healthy and no mortality occurred in any of the treatment groups except only one rat died on day 18 in the group fed on OTA-contaminated diet. The results revealed that body weight gain (Fig. 1) and food intake (Fig. 2) were significantly decreased in animals fed OTA-contaminated diet compared to the control group. Food intake and body weight gain for the groups treated with either WE or EE were comparable to the control group. However, the administration of the water extract or the ethanolic extract plus OTA could induce a significant improvement in food intake and body weight gain.

The serum biochemical analysis (Table 3) revealed a significant increase in creatinine, urea, $\mathrm{K}^{+}$and $\mathrm{NO}$ accompanied with a significant decrease in $\mathrm{Na}^{+}$in the group fed OTAcontaminated diet alone. Animals received the extracts alone showed a significant decrease only in creatinine and were comparable to the control group regarding the level of urea and $\mathrm{Na}^{+}$however; $\mathrm{K}^{+}$showed a slight increase compared to the control group. Co-administration of WE or EE with OTA improved the kidney function indices towards the control values although they were still differ significantly than the control.

The effects of both extracts on antioxidant enzyme activities (GSH-Px and SOD), total antioxidant capacity, MDA and ATP-ase in kidney tissue (Table 4) showed that OTA administration induced a significant decrease in GSH-Px, SOD, TAC and ATP-ase parallel with a significant increase in MDA. Animals treated with $\mathrm{WE}$ or $\mathrm{EE}$ alone showed a significant increase in GSH-Px and SOD however; TAC level was within the normal range of the untreated control group. Moreover, MDA level was significantly decreased in these groups but ATP-ase was significantly decreased only in the group treated with WE. Treatment with WE or EE plus OTA showed a significant improve in all the biochemical parameters tested towards the control value and succeeded to normalize TAC in both groups and ATP-ase only in the group treated with WE plus OTA (Table 4).

The results of DNA fragmentation as determined by gel electrophoresis in the kidney tissue to assess the apoptotic cell death are presented in Fig (3). OTA-contaminated diet induced a significant increase in DNA fragmentation percentage reached $56.45 \%$. However, animals treated with the extracts alone did not show any significant differences in DNA fragmentation. Administration of the extracts to the animals fed OTAcontaminated diet succeeded to induce a significant reduction in the elevation level of DNA fragmentation although these values were still higher than the control value. 


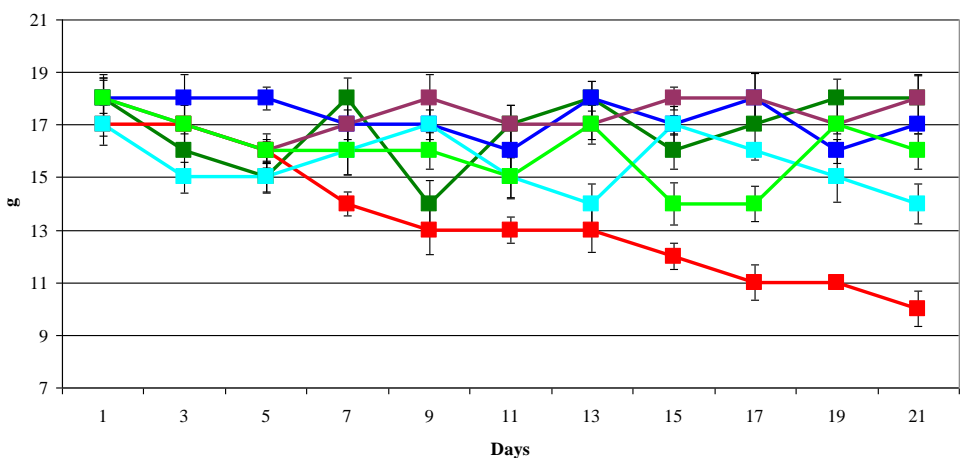

$\rightarrow-$ Control $\rightarrow-\mathrm{OTA} \rightarrow-\mathrm{WE} \rightarrow-\mathrm{EE}-\mathrm{I}-\mathrm{OTA}+\mathrm{WE}=-\mathrm{OTA}+\mathrm{EE}$

Fig. 1: Effect of WE or EE on food intake in rats fed OTA-contaminated diet

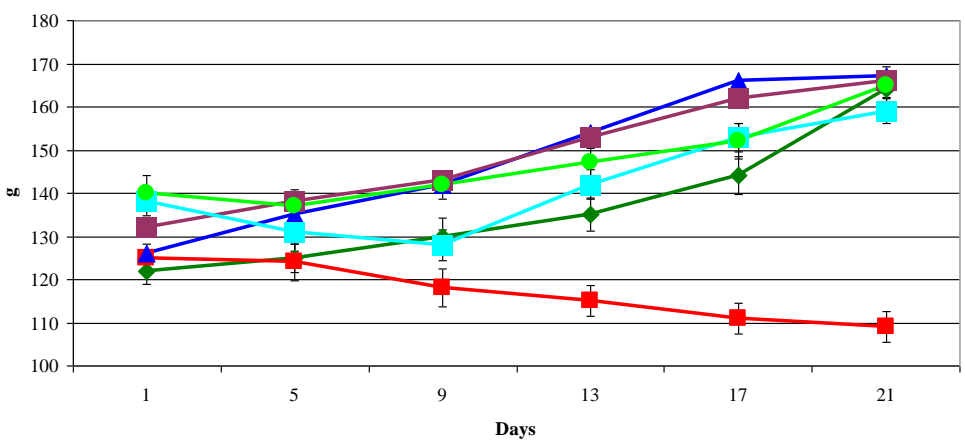

$\neg$ Control $\rightarrow$ - OTA $\rightarrow$ WE $\neg-\mathrm{EE}-$ - OTA + WE $\rightarrow-\mathrm{OTA}+\mathrm{EE}$

Fig. 2: Effect of WE or EE on body weight gain of rats fed OTA-contaminated diet

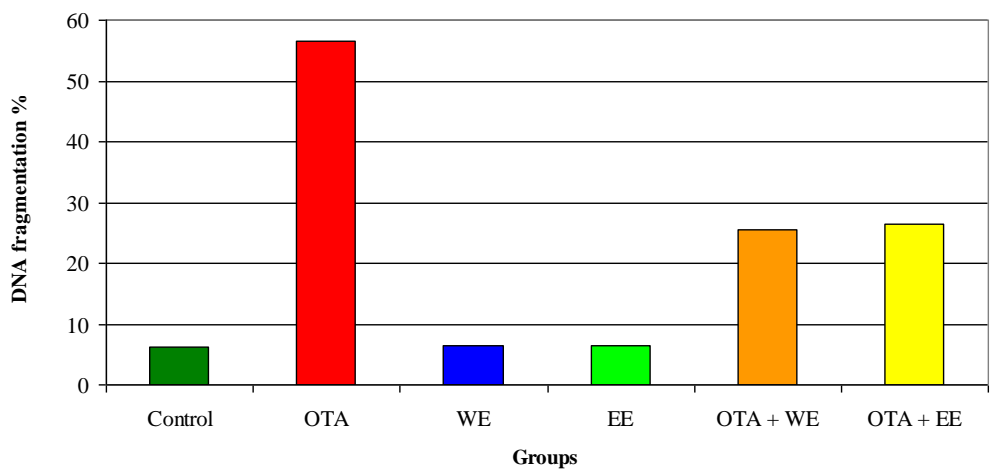

Fig. 3: Effect of WE or EE on DNA fragmentation in the kidney of rats fed OTA-contaminated diet

Table 3: Effect of water or ethanol extracts on serum biochemical parameters of kidney function in rats fed OTA-contaminated diet.

\begin{tabular}{|c|c|c|c|c|c|c|}
\hline Groups & Control & OTA & WE & EE & OTA + WE & OTA + EE \\
\hline Creatinine $(\mathrm{mg} / \mathrm{dl})$ & $0.82 \pm 0.06^{\mathrm{a}}$ & $1.17 \pm 0.04^{b}$ & $0.79 \pm 0.06^{\mathrm{c}}$ & $0.78 \pm 0.05^{\mathrm{c}}$ & $0.81 \pm 0.04^{\mathrm{a}}$ & $0.85 \pm 0.04^{\mathrm{d}}$ \\
\hline Urea $(\mathrm{mg} / \mathrm{dl})$ & $48.29 \pm 2.58^{\mathrm{a}}$ & $87.41 \pm 2.54^{\mathrm{b}}$ & $47.80 \pm 2.96^{\mathrm{a}}$ & $48.16 \pm 2.29^{\mathrm{a}}$ & $68.86 \pm 2.09^{c}$ & $65.05 \pm 4.44^{c}$ \\
\hline $\mathrm{Na}^{+}(\mathrm{mmol} / \mathrm{L})$ & $48.56 \pm 2.52^{\mathrm{a}}$ & $23.03 \pm 2.62^{\mathrm{b}}$ & $47.53 \pm 2.09^{\mathrm{a}}$ & $48.55 \pm 3.41^{\mathrm{a}}$ & $42.17 \pm 2.05^{\mathrm{c}}$ & $36.62 \pm 1.28^{\mathrm{d}}$ \\
\hline $\mathrm{K}^{+}(\mathrm{mmol} / \mathrm{L})$ & $5.34 \pm 0.51^{\mathrm{a}}$ & $9.85 \pm 0.35^{\mathrm{b}}$ & $6.03 \pm 0.61^{\mathrm{c}}$ & $6.86 \pm 0.43^{c}$ & $8.21 \pm 0.64^{\mathrm{d}}$ & $8.09 \pm 0.56^{\mathrm{d}}$ \\
\hline $\mathrm{NO}(\mu \mathrm{mol} / \mathrm{L})$ & $78.23 \pm 3.22^{\mathrm{a}}$ & $142.5 \pm 5.32^{\mathrm{b}}$ & $59.43 \pm 3.45^{\mathrm{c}}$ & $54.54 \pm 3.41^{\mathrm{c}}$ & $95.34 \pm 3.32^{\mathrm{d}}$ & $84.65 \pm 4.11^{\mathrm{e}}$ \\
\hline
\end{tabular}

Within each row, means superscript with different letter are significantly different $(\mathrm{P} \leq 0.05)$.

Table 4: Effect of WE or EE of papaya fruits on GSH-Px, SOD, TAC, MDA and ATP-ase in the kidney of rats fed OTA-contaminated diet.

\begin{tabular}{|c|c|c|c|c|c|c|}
\hline Groups & Control & OTA & WE & $\mathbf{E E}$ & OTA + WE & OTA + EE \\
\hline GSH-Px (unit/mg protein) & $250.53 \pm 4.23^{\mathrm{a}}$ & $122.73 \pm 5.32^{b}$ & $257.93 \pm 7.26^{\mathrm{a}}$ & $262.56 \pm 5.93^{\mathrm{a}}$ & $230.67 \pm 7.56^{\mathrm{c}}$ & $233.78 \pm 6.43^{\mathrm{c}}$ \\
\hline SOD (unit/mg protein) & $237.93 \pm 6.32^{\mathrm{a}}$ & $101.76 \pm 5.83^{\mathrm{b}}$ & $243.73 \pm 3.76^{\mathrm{c}}$ & $254.84 \pm 6.65^{\mathrm{d}}$ & $225.76 \pm 5.37^{\mathrm{e}}$ & $228.74 \pm 8.53^{\mathrm{e}}$ \\
\hline $\mathrm{TAC}(\mu \mathrm{mol} / \mathrm{g})$ & $27.19 \pm 0.06^{\mathrm{a}}$ & $17.14 \pm 0.07^{\mathrm{b}}$ & $27.32 \pm 0.06^{\mathrm{a}}$ & $27.48 \pm 0.03^{\mathrm{a}}$ & $27.49 \pm 0.06^{\mathrm{a}}$ & $27.37 \pm 0.11^{\mathrm{a}}$ \\
\hline $\mathrm{MDA}(\mathrm{nmol} / \mathrm{g})$ & $53.99 \pm 3.32^{\mathrm{a}}$ & $91.74 \pm 2.81^{\mathrm{b}}$ & $37.97 \pm 1.98^{c}$ & $30.38 \pm 1.02^{\mathrm{d}}$ & $32.05 \pm 2.31^{\mathrm{d}}$ & $40.09 \pm 6.19^{c}$ \\
\hline $\mathrm{Na}^{+}-\mathrm{K}^{+}$-ATPase $(\mu \mathrm{mol} \mathrm{pi} / \mathrm{hr} / \mathrm{g})$ & $339.22 \pm 6.53^{\mathrm{a}}$ & $312.82 \pm 2.20^{\mathrm{b}}$ & $331.84 \pm 2.89^{\mathrm{c}}$ & $341.61 \pm 5.18^{\mathrm{a}}$ & $339.76 \pm 4.56^{\mathrm{a}}$ & $329.17 \pm 4.40^{\mathrm{d}}$ \\
\hline
\end{tabular}

Within each row, means superscript with different letter are significantly different $(\mathrm{P} \leq 0.05)$. 
The cytogenetic analysis showed that OTA induce a serious disturbance in the kidney genes expression. Rats fed OTAcontaminated diet showed a significant decrease in $\mathrm{Cu}-\mathrm{Zn}$ SOD mRNA (Fig. 4) and GPx mRNA (Fig. 5) compared to the normal control group. Treatment with the extracts alone enhanced the gene expression of both enzymes and succeeded to induce a significant improvement in GPx mRNA and $\mathrm{Cu}-\mathrm{Zn}$ SOD mRNA gene expression. Moreover, the best results were achieved in the group treated with EE. The histological examination of the kidney of control animals or the animals treated with WE or EE showed normal structure of glomeruli, renal tubules renal corpuscle (Fig. 6A). The kidney of animals treated with OTA showed degenerated renal tubules with hyaline casts and vacuolar degeneration in the tubular epithelial cells and hyaline casts in their lumen (Fig. 6B). The microscopic examination of the kidney tissue of rats treated with OTA plus WE showed that most of renal tubules exhibit improvement except some tubules shows sclerosis, some glomeruli are normal and others are destructed (Fig. 6C). The kidney of rats fed OTA-contaminated diet and treated with EE showed nearly normal renal tubules, renal corpuscles and intertubular invasive inflammatory cells (Fig. 6D).

The histochemical examination of the kidney sections of the control rats stained with Bromophenol blue showed normal density of total protein in renal tubular epithelial cells (Fig. 7A). Animals treated with WE (Fig. 7B) or EE (Fig. 7C) showed normal distribution of bromophenol blue reaction suggested normal protein contents. The kidney of rats fed OTA-contaminated diet showed weak reaction in some tubules and mild reaction in the glomruler tufts (Fig. 7D). The kidney sections of rats treated with OTA plus WE (Fig. 7E) or EE (Fig. 7F) showed a strong reaction in the renal tubules and a moderate reaction in the glomeruli (Fig. 7E).

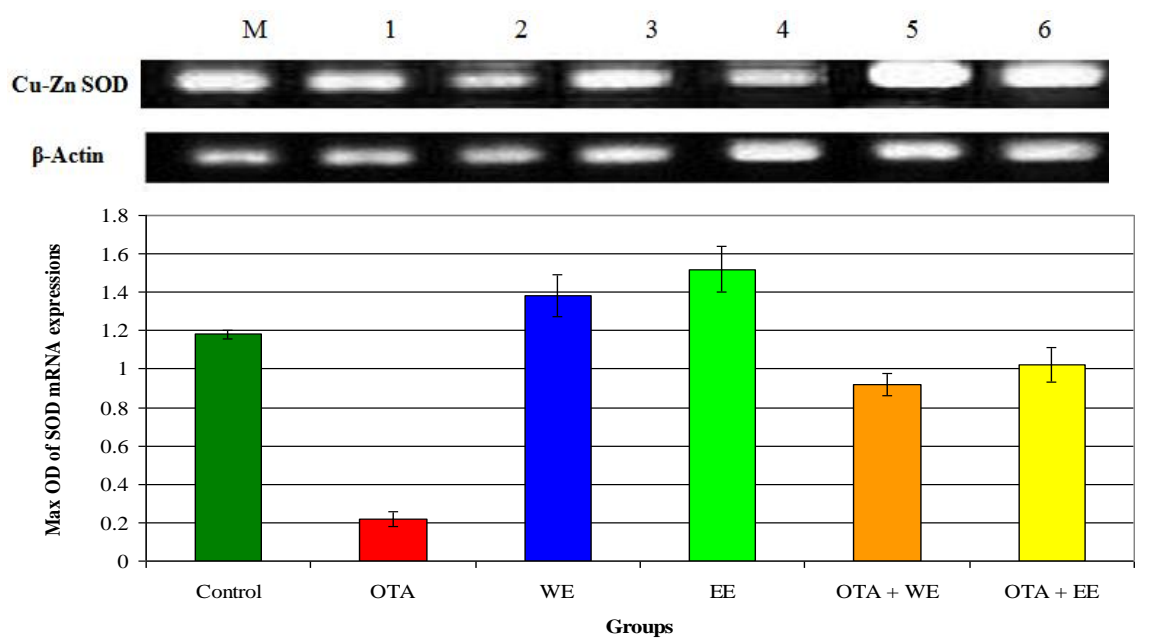

Fig. 4: Effect of We and EE of papaya fruits on the ratio between $\mathrm{Cu}-\mathrm{Zn} \mathrm{SOD} / \beta$-actin mRNA in the kidney of rat fed OTA-contaminated diet.

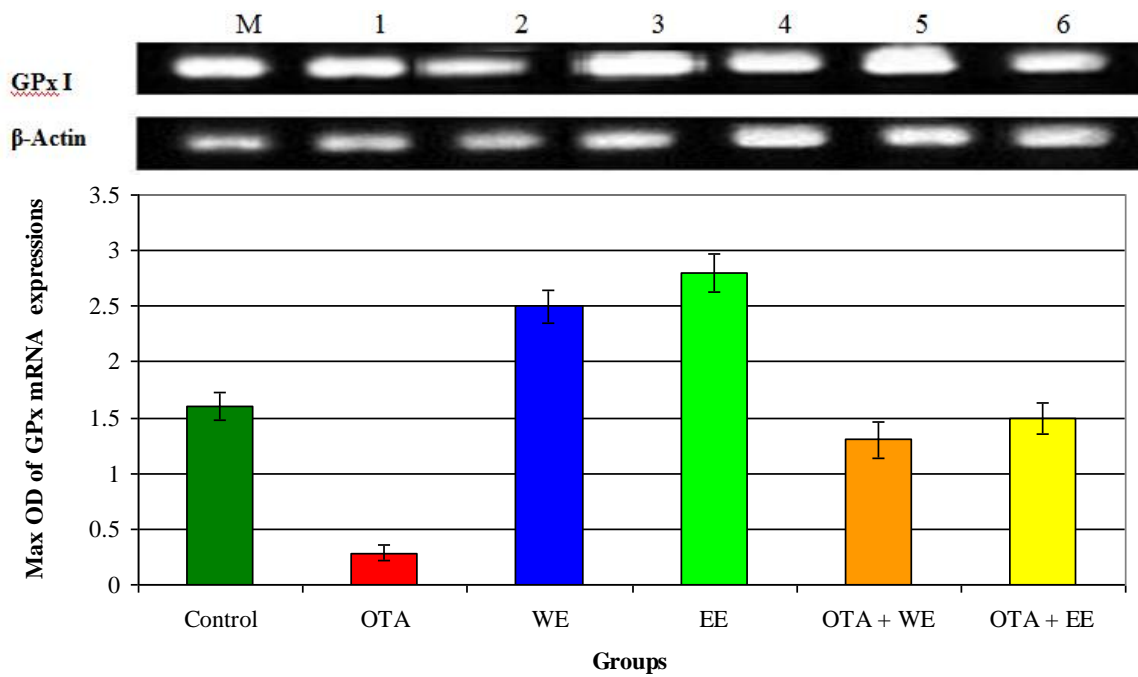

Fig. 5: Effect of WE and EE of papaya fruits on the ratio between GPx1/ $\beta$-actin mRNA in the kidney of rat fed OTA-contaminated diet. 

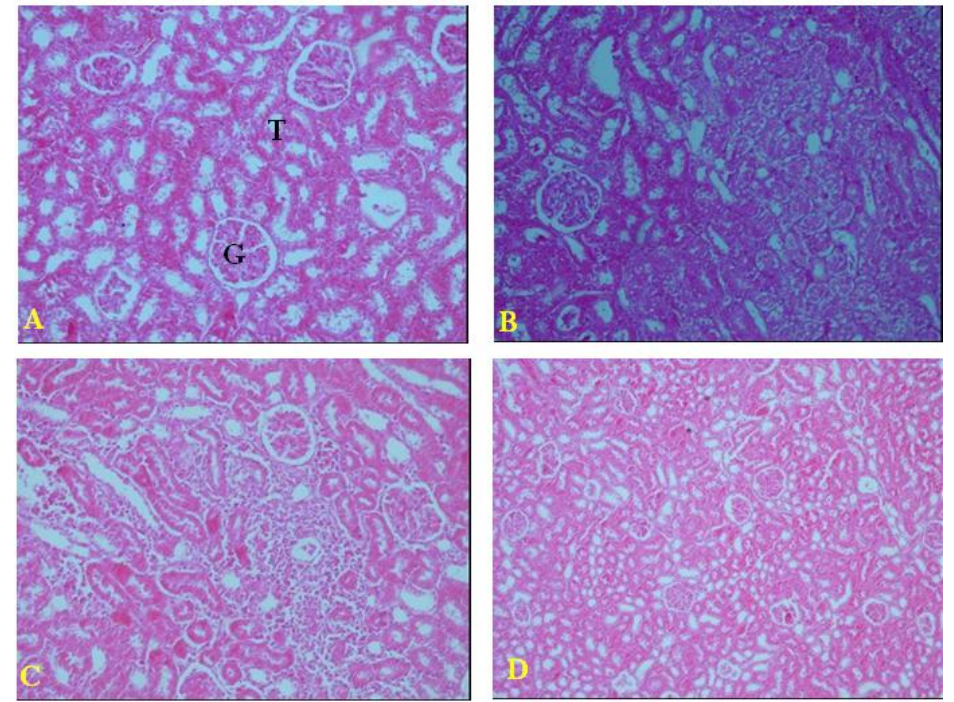

Fig. 6: A photomicrograph of a section in the kidney of (A) control rats or those treated with WE or EE showing normal structure of glomeruli (G), and renal tubules (T), (B) the kidney of rats fed OTA-contaminated diet showing degenerated renal tubules (in right side) with hyaline casts (in left side), (C) the kidney of rats fed OTA-contaminated diet and treated with WE showing improvement in most of renal tubules except some tubules shows sclerosis, some glomeruli are normal and others are destructed and (D) the kidney of rats fed OTA-contaminated diet and treated with EE showing nearly normal renal tubules and renal corpuscles and inter tubular invasive inflammatory cells.

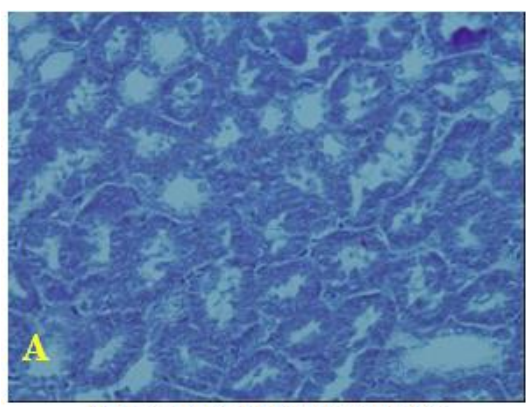

(Bromophenol blue stain $\mathrm{x} 400$ )

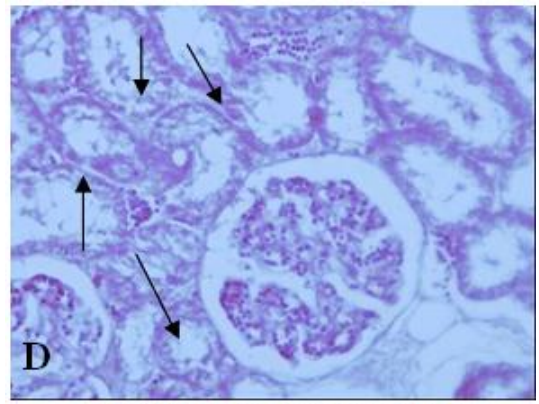

(Bromophenol blue stain $\times 400)$

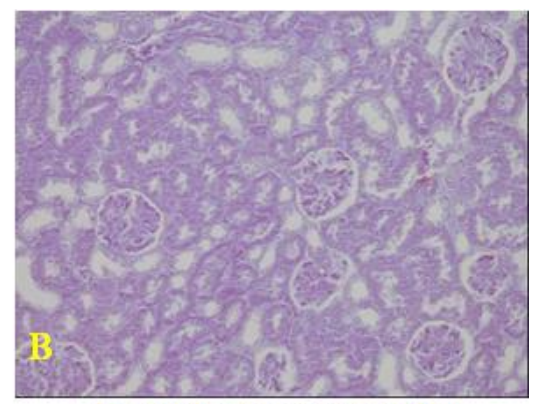

(Bromophenol blue stain $\times 300$ )

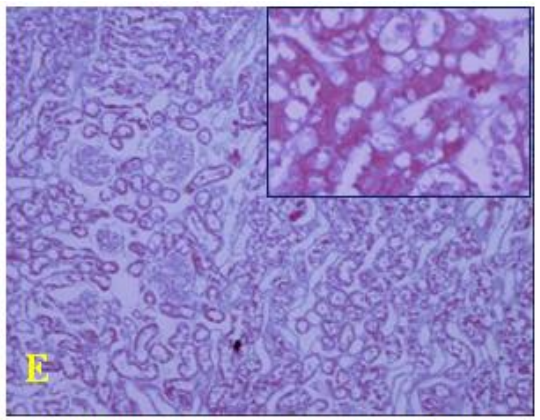

(Bromophenol blue stain $\mathrm{x} 40$, the inset $\mathrm{X} 400$ )

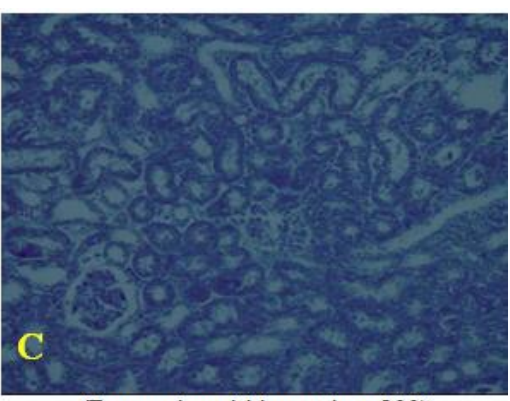

(Bromophenol blue stain $\times 300$ )

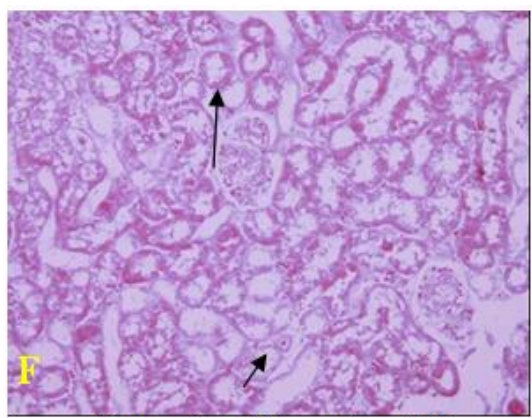

(Bromophenol blue stain $\times 300$ )

Fig. 7: A photo micrograph in kidney tissue of (A) control rat showing the normal density of total protein in renal tubular epithelial cells manifested by the blue color reaction, (B) rats treated with WE showing the normal distribution of bromophenol blue reaction, (C) rats treated with EE showing normal distribution of bromophenol blue reaction in different renal tissues, (D) rats fed OTA-contaminated diet showing the distribution of protein reaction in renal tubules, renal corpuscles and the hyaline casts revealed weak reaction in some tubules (arrow) and mild reaction in the glomruler tufts, (E) rats fed OTA-contaminated diet and treated wit WE showing strong reaction in the renal tubules (inset) and a moderate reaction in the glomeruli and (F) rats fed OTA-contaminated diet and treated with EE showing a moderate reaction in the renal tubules have moderate reaction and mild reaction in the glomeruli.

\section{DISCUSSION}

In the current study, water extract of papaya fruits showed a higher content in total phenol than the ethanolic and both extracts have a potential DPPH radical scavenging activity but was obvious in the water extract. In this concern, previous studies revealed that water extract of papaya fruits contains significant amounts of $\alpha$-tocopherol (Ching and Mohamed, 2001), benzylisothiocyanate (Basu and Haldar, 2008), alkaloids such as carpasemine and carpain (Iyer et al., 2011), lycopene (van 
Breemen and Pajkovic, 2008), proteolytic enzymes such as chymopapain and papain (Seigler et al., 2002), cystatin, ascorbic acid, cyanogenic glucosides and glucosinolates (Seigler et al., 2002), triterpenes, organic acids (Cowan, 1989; Osuna-Torres et al., 2005), as well as flavonoids (Miean and Mohamed, 2001). However, the ethanolic extract was found to be rich in sulfurous compounds (benzyl isothiocyanate) and recently Galang et al. (2016) isolated 5- $\beta$-Dglucopyranosyloxy-2-hydroxybenzoate and methyl $\beta$-D-glucopyranoside which showed significant DPPH radical scavenging capacity. According to Sancho et al., (2011), the higher DPPH radical scavenging activity for the water extract is associated with the higher total phenolic content (Babu et al., 2010).

In the in vivo assay, the water and ethanolic extract of papaya fruits were evaluated for their protective role against OTAinduced kidney damage in rats. The selected dose of OTA and papaya extracts were literature based (Abdel-Wahhab et al., 2005; Rajkapoor et al., 2002, respectively). Only one rat died on day 18 in the group fed on OTA-contaminated diet and showed signs of nephrotoxicity typical to those reported in the literature of ochratoxicosis (Malekinejad et al., 2011; Qi et al., 2014). The recorded decrease in body weight reported in the current study was primarily due to OTA and not to reduced food intake as indicated by our food restriction study. Similar to these observations, OTA was reported to induce a reduction in body weight gain and food intake in rats (Abbas et al., 2013) and broilers chicken (Nedeljković-Trailović et al., 2015; Sakthivelan and Rao, 2010).

The increase in creatinine and urea levels reported in the present study suggested the nephrotoxicity as reported earlier in different species of animals (Elaroussi et al., 2007; Kumar et al., 2008). The level of serum urea and creatinine is generally depending on their excretion through the glomerular filtration and the high level of creatinine is indicative of the impairment of kidney function (Malekinejad et al., 2011). The increased level of these markers occurred when they accumulate proportionally with the number of the destroyed nephrons and hence reflect directly the functional situation of the kidneys (Cariddi et al., 2016; Mir and Dwivedi, 2010). On the other hand the decreased levels of serum sodium and potassium reported herein suggested that OTA induced damages in the proximal tubules. It is well known that sodium presumably is reabsorbed regularly along the proximal and distal tubules (Bell et al., 1968) however; potassium is reabsorbed in the proximal and secreted in the distal tubules (Malnic et al., 1964; Pitts, 1968). Consequently, the decreased level of serum potassium indicated the impairment of its reabsorption during ochratoxicosis (Purchase and Theron, 1968; Huff et al., 1975). It is well documented that NO exhibits a wide range of biological activities under the normal conditions; on the contrary, in excess production, it may lead to the formation of a toxic radical. Actually, $\mathrm{NO}$ react with $\mathrm{O}^{2-}$ leading to the formation of the prooxidant peroxynitrite $\mathrm{ONOO}^{-}$resulting in nitrosative stress (Radi, 2004). On the other hand, the significant increase in the level of NO reported in the current study in animals treated with OTA suggesting the ability of OTA to induce overproduction of
NO in the kidney and/or other organs (e.g. the liver) resulting in the elevation of nitrate and nitrite levels (Sorrenti et al., 2012).

$\mathrm{Na}^{+}-\mathrm{K}^{+}$-ATP-ase is an enzyme located in the plasma membrane of all animal cells and helps to maintain the resting potential, the effective transport and the regulation of cellular volume (Hall et al., 2006). In most animal cells, it act as a signal transducer/integrator to regulate mitogen-activated protein kinase (MAPK) pathway, ROS, intracellular calcium beside it is responsible for the ATP-dependent transport of potassium and sodium across the cell membrane (Kulkarni et al., 2002). Moreover, $\mathrm{Na}^{+}-\mathrm{K}^{+}$-ATP-ase drives the transport of sugars and amino acids. In the present study, $\mathrm{Na}^{+}-\mathrm{K}^{+}$-ATP-ase activity was decreased in the animals fed OTA-contaminated diet suggesting the damage of cell membrane of the kidney and cell necrosis due to the oxidative stress. OTA was reported to have inhibitor effect on mitochondrial respiration which may be accounted for the impairment of renal function due to the depletion of ATP (Duarte et al., 2009). Although several mechanisms were suggested for the mode of action of OTA but the strong ATP depleting effect seems to be the most pronounced (Ringot et al., 2006).

OTA-induced oxidative stress is partially contributed to nephrotoxicity and carcinogenicity after a long term of exposure (Abdel-Wahhab et al., 2008; Baldi et al., 2004). In the current study, OTA also decreased the antioxidant enzymes GSH-Px and SOD and their gene expression as well as TAC accompanied with the elevation of MDA suggesting the conjugation between GSHPx and OTA and/or its metabolites (Abdel-Wahhab et al., 2005). Moreover, Smith-Kielland et al. (1986) reported that selenium is an essential cofactor for GSH-Px and selenium deficiency reduces the GSH-Px activity. Hence, OTA was suggested to interference with selenium absorption (Meki and Hussein, 2001). Taken together, the decreased in food intake reported herein and the interference of OTA with selenium absorption may be two reasons for the decreased activity of GSH-Px. On the other hand, SOD is a copper/ zinc-containing enzyme and is responsible for the catalytic dismutation of the highly reactive or potentially toxic superoxide radicals to hydrogen peroxide (Ozçelik et al., 2004; Sutken et al., 2007). In this concern, Meki and Hussein (2001) suggested that OTA interact with zinc and copper in SOD molecules and inhibits its activity and produces inhibition of the enzyme activity. In addition, OTA produces various changes in the cells such as the enhancement of the cell permeability to $\mathrm{Ca}^{2+}$. The increase in $\mathrm{Ca}^{2+}$ concentration in the cell beside the presence of OTA as prooxidant lead to uncouple the oxidative phosphorylation consequently increase the electrons leakage from respiratory chain, generate $\mathrm{O}^{2-}$ and hence $\mathrm{H}_{2} \mathrm{O}_{2}$ (Abdel-Wahhab et al., 2005; Ozçelik et al., 2004). This lack in the adequate supply of GSH and NAD(P)H permits the consumption of $\mathrm{H}_{2} \mathrm{O}_{2}$ by the $\mathrm{NAD}(\mathrm{P}) \mathrm{H}$ dependent GSR and GSH dependent GPx (Abdel-Wahhab et al., 2008; Hohler et al., 1997). Another mechanism for the generation of ROS by OTA is the increased of free iron concentration in the cell which stimulates the over production of $\mathrm{OH}$ through the Fenton-like reaction due to the mobilization of $\mathrm{Fe}^{2+}$ by $\mathrm{Ca}^{2+}$ (Abdel-Wahhab et al., 2005, 2008). 
The results of the present study also revealed that OTA administration induced a significant increase in the percentage of DNA fragmentation and the appearance of new bands in the animal fed OTA-contaminated diet. Although EFSA (2006) reported that OTA is not a mutagenic due to the absence of OTADNA adducts formation in rats, other strong evidences suggested that the toxicity of the kidney and the DNA damage are mainly attributable to the oxidative stress (Abdel-Wahhab et al., 2008, 2016; Bouslimi et al., 2008). According to Schaaf et al. (2002), the increase of ROS production, the decrease in antioxidants capacity and the elevation of oxidative DNA damage in proximal tubular cells may be due to ROS generation by OTA or the loss of cell viability (Mally et al., 2005a,b). Moreover, the histological and histochemical results reported herein indicated that OTA induced severe changes in the renal tissues similar to those reported in the literature (Mansour et al., 2011).

It is well documented that dietary intake of antioxidants is an effective and feasible way to boost and immunize endogenous defense systems due to their role as free radical scavenging activity resulting in the cytoprotection. In the current study, treatment with papaya extracts succeeded to ameliorate and/or counteract the oxidative stress of OTA. These results also suggested that the water extract was more effective than the ethanolic extract. According to Rajkapoor et al. (2002), the LD50 of the papaya water extract was $2516.53 \mathrm{mg} / \mathrm{kg}$ while it was $2426.37 \mathrm{mg} / \mathrm{kg}$ for the ethanolic extract which suggest the effectiveness and the safety of the water extract. Moreover, both extracts succeeded to improve body weight gain and food intake as well as induced a significant reduction in MDA and restored all the other parameters to the normal clinical ranges reported previously (Vij and Prashar, 2015). The extract also succeeded to improve the histological picture of the renal tissue.

One of the possible mechanism(s) of the protective role of the extracts against OTA-induced nephrotoxicity may be the antioxidant and/or free radical scavenging activities due to their high content of flavonoids and alkaloids (Adeneye and Benebo, 2008; Miller and Rice-Evans, 1997). These reports are in agreement with the findings of the present results which indicate that the papaya extracts are rich in total phenolic compounds and have a potential DPPH radical scavenging activity in vitro and in vivo (Olabinri et al., 2010). Moreover, polyphenols also are well known to have a wide range of biological activities including antioxidant and anti-inflammatory properties against oxidative stress and chronic inflammation (Siriwardhana et al., 2013). Previous report indicated that the high content of flavonoid, tannins, alkaloid and saponin in papaya extract induce the profound in vivo and in vitro stabilizing activity on the lysosomes of laboratory animals (Oyedapo, 2001). Moreover, plant flavonoids such as tannins, saponins and serotonin show an antioxidant activity in vitro and in vivo and stabilize the erythrocyte membrane through the binding of cations and other biomolecules (Galang et al., 2016; Santiago-Silva et al., 2011). In this concern, Imaga et al. (2010) reported that the water extract of papaya has anti-tumor effect and suppressed the proliferative responses of solid and haematopoietic tumor cell lines derived from different organs including breast and lung adenocarcinoma, cervical, hepatocellular and pancreatic epithelioid carcinoma and mesothelioma in a dose-dependent manner. According to Basu and Haldar (2008), other mechanisms for the protective role of papaya extracts against OTA-induce kidney damage via the enhanced production of Th1 type cytokines such as TNF- $\alpha$, IFN- $\alpha$, and IL12 , or through inducing a shift from Th2 to Th1 type immune response. Furthermore, Santiago-Silva et al. (2011) suggested that papaya fruits provide several functional activities due to the diversity of amines content consequently; it can be used for different nutritional needs. Taken together, the results of the in vitro and in vivo assay of the current study indicated that papaya extracts succeeded to a great extant to counteract the oxidative stress of OTA and to protect the kidney against its toxic effects.

\section{CONCLUSION}

The results of the present study concluded that the water and ethanolic extracts of papaya fruits have a potential antioxidant activity as indicated by the high concentration of total phenol and high DPPH radical scavenging activity in vitro. Treatment with OTA resulted in severe kidney injury as manifested by the disturbances in biochemical indices of kidney, the suppression of antioxidant gene expression and the increased DNA fragmentation percentage as well as the histological and histochemical changes in the kidney tissue. Both water and ethanolic extracts of papaya fruits showed a potential protective activity against the kidney injury induced by OTA through different mechanisms mainly their free radical scavenging properties and counteracting the free radical generation.

\section{ACKNOWLEDGMENTS}

Financial support and sponsorship: This work was supported by the National Research Centre, Dokki, Cairo, Egypt, project \# 10070112.

Conflict of Interests: There are no conflicts of interest.

\section{REFERENCES}

Abbas Z, Blank R, Wein S, Wolffram S. Effect of quercetin on the toxicokinetics of ochratoxin $\mathrm{A}$ in rats. Food Addit Contam Part A, 2013; 30(5): 861-866.

Abdel-Wahhab MA, Abdel-Aziem SH, El-Nekeety AA. Inula crithmoides extract protect against ochratoxin A-induced oxidative stress, clastogenic and mutagenic alterations in male rats. Toxicon, 2008; 52(4): 566-73.

Abdel-Wahhab MA, Abdel-Galil MM, Ellithey MM. Melatonin counteracts oxidative stress in rats fed Ochratoxin A- contaminated diet. J Pineal Res, 2005; 38: 130-135.

Abdel-Wahhab MA, Aljawish A, Kenawy AM, Hamed HS, ElNekeety AA, Abdel-Aziem SH. Grafting of gallic acid onto chitosan nanoparticles enhances antioxidant activities in vitro and protects against ochratoxin A toxicity in catfish (Clarias gariepinus). Environ Toxicol Pharmacol, 2016; 41: 279-288.

Adeneye AA, Benebo AS. Protective effect of the aqueous leaf and seed extract of Phyllanthus amarus on gentamicin and 
acetaminophen-induced nephrotoxic rats. J Ethnopharmacol, 2008; 118:318-323.

Babu SM, Kavitha CN, Rao MEB, Vijaykumar N, Pradeep CH. Studies on in-vitro antioxidant activities of Carica papaya aqueous leaf extract. Res J Pharm Biol Chem Sci, 2010; 1 (2): 59-65.

Baldi A, Losio MN, Cheli F, Rebucci R, Sangalli L, Fusi E, Bertasi B, Pavoni E, Carli S, Politis I. Evaluation of the protective effects of alpha-tocopherol and retinol against ochratoxin A cytotoxicity. $\mathrm{Br} \mathrm{J}$ Nutr, 2004; 91 (4): 507-512.

Basu A, Haldar S. Dietary isothiocyanate mediated apoptosis of human cancer cells is associated with Bcl-xL phosphorylation. Int $\mathrm{J}$ Oncolo, 2008; 33: 657-663.

Bell G H, Davidson JN, Scarborough H. Textbook of physiology and biochemistry, $7^{\text {th }}$ ed. The Williams \& Wilkins Co., 1968; Baltimore

Bouslimi A, Bouaziz C, Ayed-Boussema I, Hassen W, Bacha H. Individual and combined effects of ochratoxin $\mathrm{A}$ and citrinin on viability and DNA fragmentation in cultured Vero cells and on chromosome aberrations in mice bone marrow cells. Toxicology, 2008; 251(1-3):1-7.

Cariddi LN, Escobar FM, Sabini MC, Campra NA, Bagnis G, Decote-Ricardo D, Freire-de-Lima CG, Mañas F, Sabini LI, Dalcero AM. Phenolic acid protects of renal damage induced by ochratoxin $\mathrm{A}$ in a28days-oral treatment in rats. Environ Toxicol Pharmacol 2016; 43: 105-111.

Ching LS, Mohamed S. Alpha-tocopherol content in 62 edible tropical plants. J Agric Food Chem, 2001; 49: 3101-3105.

Costa J G, Saraiva N, Guerreiro PS, Louro H, Silva MJ, Miranda JP, Oliveira NG. Ochratoxin A-induced cytotoxicity, genotoxicity and reactive oxygen species in kidney cells: An integrative approach of complementary endpoints. Food Chem Toxicol, 2016; 87: 65-76.

Cowan MM. Plant products as antimicrobial agents. Clinic Microbiol Rev, 1999; 12: 564-582.

de Maria P, Dominguez, Sinistera, JB, Tsai SW, Alcantara AR. Carica Papaya lipase (CPL), an emerging and versatile biocatalyst. Biotechnol Adv, 2006; 24 (5): 493-499.

Drury RAV, Wallington EA. Carltons histological techniques, $5^{\text {th }}$ ed., Oxford University Press, New York, Pronto. 1980; pp. 206SY.

Duarte SC, Pena A, Lino CM Ochratoxin A non-conventional exposure sources - a review. Microchem J, 2009; 93: 115-120.

Duarte SC, Pena A, Lino CM. Human ochratoxin a biomarkersfrom exposure to effect. Crit Rev Toxicol, 2011; 41(3):187-212.

Elaroussi MA, Mohamed FR, Elgendy MS, El Barkouky EM, Abdou AM, Hatab MH. Ochratoxicosis in broiler chickens: functional and histological changes in target organs. Int J Poult Sci, 2008; 7: 414-422.

European Food Safety Authority (EFSA). Opinion of the scientific panel on contaminants in the food chain on a request from the commission related to Ochratoxin A. EFSA J, 2006; 365: 1-56.

FAO. Food and agriculture organization (FAO). Statistical year $\begin{array}{llll}\text { book } 2012 \quad \text { (accessed 2012; } & \text { 9.11.15.). }\end{array}$ http://www.fao.org/docrep/015/i2490e/i2490e00.htm.

Galang MG, Macabeo APG, Chang WC, Isobe M. Aguinaldo MAM. Glucosides from the unripe fruit juice of Carica papaya Linn. (Caricaceae) cultivar 'Red Lady' with antioxidant activity. J Funct Foods, 2016; $22: 358-362$.

Gibb RI, Taylor DD, Wan T, O'Connor DM, Doeriog DL, GerHel-Taylor T. Apoptosis as a measure of chemosensitivity to cisplatin and taxol therapy in ovarian cancer cell lines. Gynecol Oncol, 1997; 65: 13-22.

Hall John E, Guyton, Arthur C. Textbook of medical physiology. St. Louis, Mo: Elsevier Saunders. 2006; ISBN 0-7216-0240-1.

Heussner AH, Lewis EH, Bingle. Comparative ochratoxin toxicity: a review of the available data. Toxins, 2015; 7: 4253-4282.

Hohler D, Marquardt RR, Frohlich AA. Lipid peroxidation as one mode of action in ochratoxin A toxicity in rats and chicks. Can J Anim Sci 1997; 77: 287-292

Huet J, Looze Y, Bartik K, Raussens V, Wintjens R, Boussard P. Structural characterization of the papaya cysteine proteinases at low $\mathrm{pH}$. Biochem Biophys Res Commun, 2006; 341:620-626.

Huff WE, Wyatt RD, Hamilton PB. Nephrotoxicity of Dietary Ochratoxin A in Broiler Chickens. Appl Micobiol, 1975; 30(1): 48-51.
IARC, International Agency for Research on Cancer. Monograph on the evaluation of carcinogenic risk to humans, World Health Organization, some traditional herbal medicines, some mycotoxins, naphthalene and styrene. In Summary of data reported and evaluation 2002; (82):171-75. Lyon.

Imaga NA, Gbenle GO, Okochi VI, Adenekan S, Emmanuel TD, Oyeniyi B, Ekeh FC. Phytochemical and antioxidant nutrytent constituents of Carica papaya and parquentina nigrescens extracts. Scientific and Research Essays 2010; 5(16): 2210-2205.

Iqbal SZ, Asi MR, Zuber M, Akhtar J, Saif M J. Natural occurrence of aflatoxins and ochratoxin A in commercial chilli and chilli sauce samples. Food Control, 2013; 30: 621-625.

Iyer D, Sharma BK, Patil UK. Effect of ether- and water-soluble fractions of Carica papaya ethanol extract in experimentally induced hyperlipidemia in rats. Pharm Biol, 2011; 49(12): 1306-1310.

Jayaprakasha GKM, Tamil S, Sakariah KK. Antibacterial and antioxidant activities of grape (Vitis vinifera) seed extracts. Food Res Int, 2003; 36:117-122.

JECFA. Ochratoxin A (addendum). In: Safety evaluation of certain food additives and contaminants. Prepared by the sixty-eighth meeting of the joint FAO/WHO Expert Committee on Food Additives, 2007. WHO food additive series, Vol. 59. Geneva, Switz: Food and Agriculture Organization of the United Nations (FAO), World Health Organization (WHO). 2008; 357: 429-454.

Khan JA, Yadav J, SrivastavaY, Pal PK .In vitro evaluation of antimicrobial properties of Carica papaya. Int JBiol Pharm Allied Sci, 2012; 1(7): 933-945.

Kokila T, Ramesh PS, Geetha D. Biosynthesis of AgNPs using Carica Papaya peel extract and evaluation of its antioxidant and antimicrobial activities. Ecotoxicol Environ Saf, 2016; 134(Pt 2): 467-473.

Koracevic D, Koracevic G, Djordjevic V, Andrejevic S, Cosic V. Method for the measurement of antioxidant activity in human fluids. J Clini Pathol, 2001; 54: 356-361.

Kulkarni KS, Rafiq MD, Gopumadhavan S, Venkataranganna MV, Madhumathi BG, Mitra SK. Protective effect of Liv.52 on Na+-K+ATPase activity in Paracetamol-induced hepatotoxicity. Med Update, 2002; 10(5): 53-56.

Kumar M, Dwivedi P, Sharma AK, Telang AG, Patil RD, Singh ND, Sangar M. Ochratoxin-A and citrinin induced biochemical changes in New Zealand white rabbits. Indian J Vet Pathol, 2007; 31: 135-139.

La Marca M, Beffy P, Della Croce C, Gervasi P, Iori R, Puccinelli E, Longo V. Structural influence of isothiocyanates on expression of cytochrome P450, phase II enzymes, and activation of Nrf2 in primary rat hepatocytes. Food Chem Toxicol, 2012; 50(8): 2822 2830 .

Limaye PV, Raghuram N, Sivakami S. Oxidative stress and gene expression of antioxidant enzymes in the renal cortex of streptozotocin induced diabetic rats. Mol and Cellr Biochem, 2003; 243: $147-152$

Malekinejad H, Farshid AA, Mirzakhani N. Liquorice plant extract reduces ochratoxin A-induced nephrotoxicity in rats. Exp Toxicol Pathol, 2011; 63:125-130.

Mally A, Pepe G, Ravoori S, Fiore M, Gupta RC, Dekant W, Mosesso P. Ochratoxin A causes DNA damage and cytogenetic effects but DNA adducts in rats. Chem Res Toxicol, 2005a; 18: 1253 1261.

Mally A, Völkel W, Amberg A, Kurz M, Wanek P, Eder E, Hard G, Dekant W.. Functional, biochemical and pathological effects of repeated oral administration of ochratoxin A to rats. Chem Res Toxicol, 2005b; 18: 1242-1252.

Malnic, G., R. N. Klose, and G. Giebisch. Micropuncture study of renal potassium excretion in the rat. Am J Physiol, 1964; 206: 674-686.

Mansour TA, Mohamed SG, Soliman MK, Omar EA, Srour TM, Zaki, MS, Hassan SMS. Ameliorate the drastic effect of Ochratoxin A by using yeast and whey in cultured Oreochromus niloticus in Egypt. Life Sci J, 2011; 8(1): 68-81

Märtlbauer E, Usleber E, Dietrich R, Schneider E. Ochratoxin A in human blood serum retrospective long-term data. Mycotoxin Res, 2009; 25(4):175-86. 
Meki MA, Hussein AA. Melatonin reduces oxidative stress induced by ochratoxin A in rat liver and kidney. Comp Biochem Physiol, 2001; 130: 305-313.

Miean KH, Mohamed S. Flavonoid (myricetin, quercetin, kaempferol, luteolin, and apigenin) content of edible tropical plants. J Agric Food Chem, 2001; 49: 3106-3112.

Miller NJ, Rice-Evans CA. Factors influencing the antioxidant activity determined by the ABTS radical cation assay. Free Rad Res, 1997; 26: 195-199.

Mir MS, Dwivedi P. Ochratoxin A-induced serum biochemical alterations in New Zealand white rabbits (Oryctolagus cuniculus). Turk J Vet Anim Sci, 2010; 34(6): 525-531.

Nedeljković-Trailović J, Trailović S, Resanović R, Milićević D, Jovanovic M, Vasiljevic M. Comparative investigation of the efficacy of three different adsorbents against OTA-induced toxicity in broiler chickens. Toxins (Basel), 2015; 7(4):1174-1191.

Nogala-Kalucka M, Korczak J, Dratwia M, Lampart-Szczapa E, Singer A, Buchowski M. Changes in antioxidant activity and free radical scavenging potential of rosemary extract and tocopherols in isolated rapeseed oil triacylglycerol during accelerated tests. Food Chem, 2005; 93 : 227-235.

Olabinri BM, Olaleye MT, Bello OO, Ehigie LO, Olbinri PF. In vitro comparative antioxidative potentials of mango and pawpaw leaf extract. Int J Trop Med, 2010; 5(2): 40-45.

Osuna-Torres L, Tapia-Pérez ME, Aguilar-Contreras A. Plantas medicinales de la medicina tradicional mexicana para tratar afecciones gastrointestinales: Estudio etnobotánico fitoquimico y farmacológico. 2005 ; Universidat de Barcelona, Barcelona.

Oyedapo OO. Biological activity of Phyllanthus armarus extract on Pragrow-Dawley rats. Nigerian J Biochem Mol Biol, 2001; 26: 202-226.

Ozçelik N, Soyöz M, Kilinç I. Effects of ochratoxin a on oxidative damage in rat kidney: protective role of melatonin. J Appl Toxicol, 2004; 4(3): 211-215.

Paes J, da Cunha C R, Viotto LA. Concentration of lycopene in the pulp of papaya (Carica papaya L.) by ultrafiltration on a pilot scale. Food Bioprod Process, 2015; 96: 296-305.

Pfohl-Leszkowicz RA, Manderville. Ochratoxin A: an overview on toxicity and carcinogenicity in animals and humans. Mol Nutr Food Res, 2007; 51 (1): 61-99.

Pitts RF. Physiology of the kidney and body fluids, $2^{\text {nd }}$ ed. Year Book Medical Publishers, Inc., 1968; Chicago.

Purchase JFH, Theron JJ. The acute toxicity of ochratoxin A to rats. Food Cosmet Toxicol, 1968; 6: 479-483.

Qi X, Yua T, Zhua L, Gao J, He X, Huanga K, Luoa Y, Xu W. OchratoxinA induces rat renal carcinogenicity with limited induction of oxidative stress responses. Toxicol Appl Pharm, 2014; 280: 543-549.

Raben N, Nichols RC, Martiniuk F, Plotz PH. A model of mRNA splicing in adult lysosomal storage disease (glycogenosis type II), Hum Mol Genet, 1996; 5: 995-1001.

Radi R. Nitric oxide, oxidants, and protein tyrosine nitration. Proc Natl Acad Sci USA 2004; 101: 4003-4008.

Rajkapoor B, Jayakar B, Kavimani S, Murugesh N. Effect of dried fruits of Carica papaya linn on Hepatotoxicity. Biol Pharm Bull, 2002; 25 : 1645-1646.

Ringot D, Chango A, Schneider YJ, Larondelle Y. Toxicokinetics and toxico-dynamics of ochratoxin A, an update, Chem Biol Interact, 2006; 159: 18-46.

Ruiz-Larnea MB, Leal AM, Liza M, Lacort M, deGroot $\mathrm{H}$. Antioxidant effects of estradiol and 2-hydroxyestradiol on iron induced lipid peroxidation of rat liver microsome. Steriod, 1994; 9: 383-388.

Sakthivelan SM, Rao GVS. Effect of Ochratoxin A on body weight, feed intake and feed conversion in Broiler chicken. Vet Med Int, 2010; Article ID 590432, 4 pages

Sancho LGG, Yehia EM, Gonzalez-Aguilar GA. Identification and quantification of phenols, carotenoids, and vitamin C from papaya (Carica papaya L., cv. Maradol) fruit determined by HPLC-DADMS/MS-ESI. Food Res Int, 2011; 44(5): 1284-1291.
Santiago-Silva P, Labanca RA, Beatriz M, Gloria A. Functional potential of tropical fruits with respect to free bioactive amines. Food Res Int, 2011; 44: 1264-1268.

Santos L, Mar'in S, Sanchis V, Ramos AJ. Co-occurrence of aflatoxins, ochratoxin $\mathrm{A}$ and zearalenone in capsicum powder samples available on the Spanish market. Food Chem, 2010; 122(3): 826-830.

SAS Institute, Inc. SAS User's Guide: Statistics. SAS Inst., Inc., Gary, 1982; NC.

Schaaf GJ, Nijmeijer SM, Maas RFM, Roestenberg P, de Groene EM, Fink-remmels J. The role of oxidative stress in the ochratoxin A-mediated toxicity in proximal tubular cells. Biochim Biophys Acta, 2002; 1588: 149-158.

Seigler DS, Pauli GF, Nahrstedt A, Leen R. Cyanogenic allosides and glucosides from Passiflora edulis and Carica papaya. Phytochemistry, 2002; 60: 873-882.

Siriwardhana N, Kalupahana NS, Cekanova M, LeMieux M, Greer B, Moustaid-Moussa N. Modulation of adipose tissue inflammation by bioactive food compounds. J Nutr Biochem, 2013; 24(4): 613-623.

Smith-Kielland A, Aaseth J, Thomassen Y. Effectof long-term ethanol intake on the content of selenium in rat liver: relation to the rate of hepatic protein synthesis. Acta Pharmacol Toxicol, (Copenhagen), 1986; 58: $237-239$

Sorrenti V, Di Giacomo C, Acquaviva R, Bognanno M, Grilli E, D’Orazio N, Galvano F. Dimethylarginine Dimethylaminohydrolase/Nitric Oxide Synthase Pathway in Liver and Kidney: Protective Effect of Cyanidin 3-O- $\beta$-D-Glucoside on Ochratoxin-A Toxicity. Toxins, 2012; 4 : 353-363.

Soto JB, Ruiz MJ, Manyes L, Juan-García A. Blood, breast milk and urine: potential biomarkers of exposure and estimated daily intake of ochratoxin A: a review. Food Addit Contam Part A Chem Anal Control Expo Risk Assess, 2016; 33(2): 313-238.

Sutken E, Aral E, Ozdemir F, Uslu S, Alatas O, Colak O. Protective role of melatonin and coenzyme Q10 in ochratoxin A toxicity in rat liver and kidney. Int J Toxicol, 2007; 26(1): 81-87.

Tsakiris S, Angelogianni P, Schulpis KH, Belrakis P. Protective effect of L-cysteine and glutathione on rat brain $\mathrm{Na} / \mathrm{K}+$-ATPase inhibition induced by free radical. Zeitschrift für Naturforschung, 2000; 55: 271-277.

Urquiaga I, Leighton F. Plant polyphenol antioxidants and oxidative stress. Biolo Res, 2000; 33(2): 55-64.

Van Breemen RB, Pajkovic N. Multitargeted therapy of cancer by lycopene. Cancer Lett, 2008; 269: 339-351.

Varga J, Kevei E, Rinyu E, Téren J, Kozakiewicz Z. Ochratoxin production by Aspergillus species. Appl Environ Microbiol, 1996; 62: 4461-4464.

Vij T, Prashar Y. A review on medicinal properties of Carica papaya Linn. Asian Pac J Trop Dis, 2015; 5(1): 1-6.

Waller RA, Duncan, DB. A Bayes rule for the symmetric multiple comparisons problem. J Am Stati Asso, 1969; 64 (328): 1484 1503.

WHO. Safety evaluation of certain food additives and contaminants. WHO Food Additives Series, 2008; No. 59.

Xiao H, Marquardt KR, Abramson D et al. Metabolites of ochratoxins in rat urine and in a culture of Aspergillus ochraceus. Environ Microbiol, 1995; 62: 648-655.

\section{How to cite this article:}

El-Nekeety AA, Abdel-Wahhab KG, Abdel-Aziem SH, Mannaa FA, Hassan NS, Abdel-Wahhab MA, Papaya fruits extracts enhance the antioxidant capacity and modulate the genotoxicity and oxidative stress in the kidney of rats fed ochratoxin A-contaminated diet. J App Pharm Sci, 2017; 7 (07): 111-121. 